\title{
ANALISIS KERAJINAN SOUVENIR DIORAMA BERBAHAN LIMBAH PADA PENGRAJIN DIKRAF BERDASARKAN PRINSIP-PRINSIP DESAIN
}

\author{
Lisa Andriani Saragih ${ }^{*}$, Zulkifli $^{\text {* }}$ \\ Program Studi Pendidikan Seni Rupa Jurusan Seni Rupa Fakultas Bahasa dan Seni \\ Universitas Negeri Medan \\ Jl. Willem Iskandar Pasar V Medan Estate, Kec, Percut Sei Tuan, Kab. Deli Serdang, Kode Pos 20371 \\ Sumatera Utara. Indonesia \\ Email: lisaandrianisaragih@gmail.com
}

\begin{abstract}
Abstrak
Penelitian ini bertujuan untuk mendeskripsikan prinsip-prinsip desain yang terdapat pada karya kerajinan souvenir diorama berbahan limbah pada pengrajin Dikraf. Metode pengumpulan data penelitian ini adalah observasi, wawancara dan dokumentasi. Jumlah populasi penelitian 70 karya keseluruhan yang ada pada pengrajin Dikraf. Teknik pengambilan sampel penelitian adalah purposive sampling, yaitu teknik pengambilan sampel sumber data dengan pertimbangan tertentu sebanyak 10 sampel. Hasil penelitian menunjukkan bahwa penerapan prinsip-prinsip desain yaitu prinsip kesatuan, keseimbangan, irama, penekanan, dan proporsi berdasarkan hasil nilai rata-rata yang telah dinilai oleh 3 tim penilai secara keseluruhan pada karya kerajinan souvenir diorama berbahan limbah sudah diterapkan dengan baik. Penerapan prinsip kesatuan memperoleh nilai baik dengan presentase $80 \%$, cukup baik $10 \%$, dan kurang baik $10 \%$. Penerapan prinsip keseimbangan memperoleh nilai amat baik dengan presentase $10 \%$, baik $60 \%$, dan cukup baik 30\%. Penerapan prinsip irama memperoleh nilai baik dengan presentase $50 \%$, cukup baik $40 \%$, dan kurang baik $10 \%$. Penerapan prinsip penekanan memperoleh nilai baik dengan presentase 90\%, dan cukup baik 10\%. Penerapan prinsip proporsi memperoleh nilai baik dengan presentase $90 \%$ dan cukup baik $10 \%$. Hasil penelitian menjelaskan bahwa kesatuan secara keseluruhan baik karena tiap elemennya dikomposisikan dengan baik dan warna pada tiap objeknya terlihat harmonis. Keseimbangan secara keseluruhan baik karna adanya pengaruh arah pandang boneka dan penempatan tiap elemenya terlihat seimbang dan dapat dirasakan melalui kepekaan estetis. Irama secara keseluruhan cukup baik karena tidak memiliki banyak elemen yang disusun rapi dan berulang-ulang. Penekanan secara keseluruhan baik karena adanya kontras warna dan bentuk yang menonjol pada karya. Proporsi secara keseluruhan baik karena pada boneka memiliki bentuk tubuh dan ukuran yang unik. Potensi pengembangan pada prinsip kesatuan dan irama dilakukan dengan cara menambah jumlah elemen pendukung pada setiap karya. Pada prinsip keseimbangan dan proporsi dilakukan dengan mempertimbangkan ukuran dan bentuk serta banyaknya elemen pendukung pada karya yang digunakan. Pada prinsip penekaan dilakukan dengan pemilihn bentuk, ukuran serta warna yang menonjol atauapun kontras dari elemen lainnya.
\end{abstract}

Kata Kunci: kerajinan, souvenir diorama, prinsip desain.

\begin{abstract}
This study a This study aims to describe the design principles contained in souvenir craft diorama made from waste from Dikraf craftsmen. Data collection methods of this study are observation, interviews and documentation. The number of research population is 70 overall works in Dikraf craftsmen. The sampling technique of the study was purposive sampling, which is the sampling technique of data sources with certain considerations as many as 10 samples. The results showed that the application of design principles namely the principle of unity, balance, rhythm, emphasis, and proportion based on the results of the average value that had been assessed by the 3 assessment teams as a whole in the craft of souvenirs diorama made from waste has been applied well. The application of the principle of unity is to get good grades with a percentage of $80 \%$, good enough at $10 \%$, and less than $10 \%$. The application of the principle of equilibrium gets very good value with a percentage of $10 \%$, both $60 \%$, and good enough $30 \%$. The application of the rhythm principle obtains a good value with a percentage of 50\%, 40\% good enough, and 10\% less good. The application of the principle of emphasis obtains good grades with a percentage of $90 \%$, and is good enough at $10 \%$. The application of the principle of proportion obtains a good value with a percentage of $90 \%$ and is quite good at $10 \%$. The results of the study explain that overall unity is good because each element is well composed and the color of each object looks harmonious. Overall balance is good because of the influence of the direction of view of the doll and the placement of each element looks balanced and
\end{abstract}




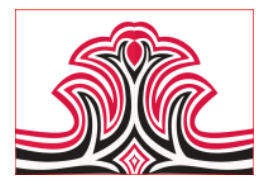

Gorga Jurnal Seni Rupa

Volume 08 Nomor 01 Januari-Juni 2019

p-ISSN: 2301-5942 | e-ISSN: 2580-2380

can be felt through aesthetic sensitivity. The rhythm as a whole is quite good because it doesn't have many elements arranged neatly and repeatedly. The overall emphasis is good because of the contrast of colors and shapes that stand out in the work. The overall proportion is good because the doll has a unique body shape and size. Potential development on the principle of unity and rhythm is done by increasing the number of supporting elements in each work. The principle of balance and proportion is done by considering the size and shape and the number of supporting elements in the work used. In the principle of sensitization is done by choosing the shape, size and color that stands out or even the contrast of other elements.

Keywords: crafts, diorama souvenirs, design principles.

\section{PENDAHULUAN}

Kerajinan merupakan karya manusia yang berkaitan dengan keterampilan tangan dan memiliki nilai estetis, sehingga karya tersebut memiliki nilai jual. Karya kerajinan biasanya terbuat dari berbagai bahan dan memiliki fungsi sebagai benda hias maupun benda pakai. Salah satu pengrajin di kota Medan yang mampu memanfaatkan limbah menjadi sebuah produk kerajinan adalah Dikraf. Dikraf merupakan salah satu usaha kerajinan yang bergerak dalam pembuatan miniatur, lukisan dari bahan serbuk kayu, lampu hias serta boneka yang terbuat dari bahan limbah karung goni. Dengan memanfaatkan bahan limbah, pengrajin Dikraf mampu menyulap bahan tersebut menjadi sebuah kerajinan yang unik dan memiliki nilai jual.

Dari berbagai produk kerajinan yang dihasilkan Dikraf, peneliti sangat tertarik untuk meneliti karya boneka yang terbuat dari bahan limbah karung goni. Boneka tersebut merupakan boneka figure yang memiliki keunikan tersendiri karena terbuat dari bahan limbah karung goni. Boneka tersebut berukuran kecil dan memiliki unsur pendukung yang juga terbuat dari bahan limbah lainnya yang dipadukan sehingga menimbulkan kesan cerita didalamnya yang bisa kita sebut sebagai kerajinan souvenir diorama. Dari keunikan karya diorama yang dihasilkan oleh pengrajin Dikraf, ternyata dalam pembuatannya masih terdapat beberapa kelemahan yang berkaitan dengan prinsip-prinsip desain. Peneliti melihat bahwa karya diorama terlihat sangat sederhana dikarenakan elemen pendukung berupa bahan yang digunakan oleh pengrajin Dikraf sangat minim.

\section{KAJIAN TEORI}

\section{Pengertian Analisis}

Analisis adalah suatu kegiatan yang dilakukan untuk mencari solusi dari berbagai permasalahan dengan cara menghubungkan unsur-unsur yang terkait kemudian memaparkannya dan menarik kesimpulan agar mudah dipahami.

\section{Pengertian Kerajinan}

Menurut Raharjo (2011:16) mengatakan bahwa: kerajinan adalah suatu hal yang bernilai sebagai kreativitas alternatif, suatu barang yang dihasilkan melalui keterampilan tangan. Umumnya barang kerajinan banyak dikaitkan dengan unsur seni yang kemudian disebut seni kerajinan. Seni kerajinan adalah implementasi dari karya seni kriya yang telah diproduksi secara massal (mass product).

\section{Pengertian Souvenir}

Menurut Wulansendow (2016:122) mengatakan bahwa: souvenir merupakan barang-barang kerajinan tangan (handy craft) yang merupakan hasil kreativitas para pengrajin yang mampu merubah benda-benda yang terbuang dan tidak berharga menjadi produkproduk kraft tangan yang menarik dan diminati banyak orang, terutama para wisatawan.

\section{Pengertian Diorama}

Menurut Yudhi (2013:109) mengatakan bahwa: diorama merupakan pemandangan tiga dimensi dalam ukuran kecil untuk memperagakan atau menjelaskan suatu keadaan atau fenomena yang menunjukan aktivitas. Dalam diorama terdapat benda-benda yang berukuran kecil. Benda kecil tersebut dapat berupa orang-orangan, pohon-pohonan, rumah-rumahan dan lain-lain, sehingga tampak seperti dunia yang sebenarnya dalam ukuran mini.

Selanjutnya Griffith (2013:9) dalam buku nya Ship Dioramas Bringing Your Models to Life mengemukakan bahwa: diorama mencakup hal-hal seperti: terdiri lebih dari satu model, berada di selain dasar polos, dan menceritakan sebuah kisah atau mengilustrasikan tema. Kemudian Griffith juga menjelaskan sedikit tentang karakteristik yang harus di tunjukkan dalam membuat sebuah diorama agar terlihat baik, diantaranya yaitu:

1) Diorama harus secara visual menyenangkan dan memuaskan mental.

2) Dioarama seharusnya tidak membosankan.

3) Diorama harus memiliki titik fokus.

4) Diorama harus memiliki cukup 'barang' didalamnya, tetapi tidak terlalu banyak.

5) Diorama harus menceritakan sebuah kisah atau menceritakan sebuah tema. 


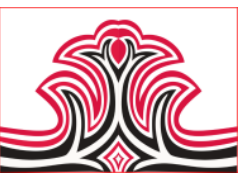

\section{Prinsip-Prinsip Desain}

Kesatuan (unity) adalah bagian dari prinsip komposisi tata rupa, yang harus diperhatikan dalam berkarya seni rupa. Kesatuan atau disebut juga keutuhan adalah kualitas hubungan antara bagian-bagian dari elemen komposisi yang menyatu, baik dalam bentuk visual ataupun tema (content). Kesatuan atau kepaduan muncul didalam ketunggalan. Bagian yang satu dengan yang lainnya saling terkait, saling menentukan, saling mendukung dan sistemik mewujudkan keutuhan visualisasi karya. Tanpa adanya kesatuan karya seni maupun desain akan terlihat cerai berai (Zulkifli, 2018:45).

Meurut Stewart (2011:22) menjelaskan bahwa keseimbangan mengacu pada distribusi berat atau kekuatan di antara unit-unit visual. Seperti keseimbangan fisik, keseimbangan visual membutuhkan keseimbangan dalam ukuran, berat visual, dan gaya. Keseimbangan visual dapat diciptakan melalui ketiadaan serta kehadiran bentuk.

Irama dalam karya seni rupa mejadikan suatu karya menjadi hidup, tidak membosankan. Menjadikan karya seolah punya kekuatan dan tidak monoton, tidak membosankan. Sehingga karya punya kekuatan dan dinamika psikologi. Pengertian irama dalam seni rupa adalah gerak perulangan secara teratur dan terusmenerus (Zulkifli, 2018:50).

Selanjutnya Stewart (2011:234) mengatakan bahwa: irama dapat didefinisikan sebagai organisasi dari beberapa elemen atau efek ini menjadi pola yang disengaja. Sama seperti seorang musisi menciptakan pola yang disengaja dengan menghubungkan suara dan keheningan, sehingga sang seniman dapat menciptakan ritme menggunakan bentuk positif dan ruang negatif.

Penekanan/emphasiss adalah suatu elemen yang paling menonjol, unik, memiliki kekhasan tersendiri, baik itu dalam segi bentuk, bahan, warna, yang berbeda dari elemen-elemen yang lainnya yang terdapat pada suatu karya/benda dan menjadi pusat perhatian bagi para pengamat.

Selanjutnya Stewart (2011:231) menyatakan bahwa: penekanan memberikan keunggulan khusus untuk bagian dari desain. Titik fokus adalah merancang komposisi yang digunakan untuk menciptakan penekanan. Baik penekanan dan titik fokus digunakan untuk menarik perhatian dan meningkatkan dampak visual dan konseptual.
Gorga Jurnal Seni Rupa

Volume 08 Nomor 01 Januari-Juni 2019

p-ISSN: 2301-5942 | e-ISSN: 2580-2380

Proporsi adalah perbandingan suatu ukuran antara satu dengan lainnya dan satu dengan keseluruhannya. Misalnya perbandingan ukuran panjang kaki manusia dengan panjang tangannya. Pada suatu karya, proporsi bisa dilihat pada pengaturan ukuran bidang alas dengan elemen-elemen karya tersebut. Proporsi yang tidak tepat akan membuat sebuah karya menjadi tidak enak dipandang. Maka dari itu, dalam pembuatan sebuah karya, proporsi juga menjadi suatu pertimbangan yang penting agar karya tersebut menarik.

\section{METODE PENELITIAN}

Dalam suatu penelitian, metode memegang peranan yang sangat penting. Hal ini disebabkan karena semua kegiatan yang dilakukan dalam penelitian sangat bergantung kepada metode yang digunakan. Adapun metode yang digunakan dalam penelitian ini adalah metode deskriptif, dan teknik analisis kualitatif dengan langkah-langkah sebagai berikut : observasi, wawancara dan dokumentasi. Sesuai dengan masalah yang diteliti, maka penelitian ini akan dilaksanakan di Jl. Amaliun 1 Gg. Sawo No. 9 Medan. Adapun yang menjadi populasi dalam penelitian ini yaitu 10 karya souvenir diorama dari bahan limbah milik pengrajin Dikraf.

Menurut Sugiyoni (2014:118) mengatakan bahwa: sampel adalah bagian dari jumlah dan karakteristik yang dimiliki oleh populasi tersebut. Bila populasi besar, dan peneliti tidak mungkin mempelajari semua yang ada pada populasi, misalnya karna keterbatasan dana, tenaga dan waktu, maka peneliti dapat menggunakan sampel yang diambil dalam populasi itu.

Dalam buku Metode Penelitian Pendidikan dikatakan bawa purposivve sampling adalah teknik pengambilan sampel sumber data dengan pertimbangan tertentu (Sugiyono, 2014:300). Selanjutnya menurut Arikunto (2010:33), purposive sampling yaitu menentukan sampel dengan pertimbangan tertentu yang dipandang dapat memberikan data secara maksimal. Dari pernyataan diatas maka peneliti telah mempertimbangkan pemilihan sampel yang nantinya akan diteliti dengan jumlah kurang dari setengah populasi. Sampel yang dipilih peneliti keseluruhannya adalah karya kerajinan souvenir diorama berbahan limbah yang berjumlah 10 karya dikarenakan ada beberapa karya pada pengrajin Dikraf yang memiliki bentuk yang sama dan apabila seluruh populasi karya diorama digunakan sebagai sampel, maka tidak lagi memberikan informasi yang baru dan berarti. 


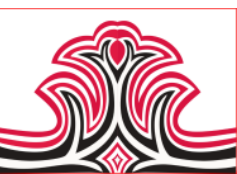

Observasi berarti pengamatan dan pencatatan secara sistematis terhadap suatu gejala yang tampak pada objek penelitian. Observasi terdiri dari observasi langsung dan observasi tidak langsung. Dalam penelitian ini peneliti menggunakan observasi langsung. Observasi langsung dilakukan dengan cara meninjau langsung ketempat penelitian yang berada di Jl. Alumunium $1 \mathrm{Gg}$. Sawo No. 9 Medan untuk melakukan pengamatan langsung dan pengumpulan data mengenai karya diorama boneka di pengrajin Dikraf.

Wawancara adalah suatu kegiatan yang dilakukan peneliti untuk mendapatkan data informasi melalui proses tanya jawab yang dilakukan oleh dua orang atau lebih, antara peneliti dengan narasumber atau peneliti dengan pengrajin. Kegiatan tanya jawab juga bisa dilakukan secara langsung maupun tidak langsung. Tanya jawab secara langsung dalam penelitian ini dilakukan secara face to face atau bertatap muka antara peneliti dengan pengrajin. Sementara tanya jawab secara tidak langsung dilakuka melaui media sosial antara peneliti dengan pengrajin.

Dokumentasi adalah suatu proses pengumpulan data dengan cara pengambilan gambar melalui intrumen yang berupa kamera sebagai bukti penelitian. Selain itu, dokumentasi pada penelitian ini juga berupa lembar penilaian hasil karya boneka yang telah dinilai oleh tim penilai yang terdiri dari 2 orang dosen Universitas Negeri Medan dan 1 orang dari owner advertising yang dianggap mampu menjadi penilai dalam penelitian ini.

Tim penilai dalam penilaian karya souvenir diorama berbahan limbah yaitu sebagai berikut:

1) Drs. Heri Soeprayogi, M.Si. (Dosen Mata Kuliah Patung)

2) Drs. Misgiya, M.Hum. (Dosen Mata Kuliah Desain Produk)

3) Yan Hendra, S.Kom. (Owner OP Advertising and Merchandies yang sudah lama bergelut dibidang Design)

Dalam penelitian ini teknik analisis data yang digunakan peneliti adalah deskriptif kualitatif dimana data yang diperoleh diuraikan dengan menggunakan kata-kata berbentuk narasih atau gambaran yang sejelas-jelasnya berdasarkan fakta yang diperoleh peneliti dilapangan dan data berupa angka diperoleh dari tim penilai kerajinan souvenir diorama yang menjadi sampel penelitian.

Langkah-langkah yang dilakukan peneliti pada saat melakukan penelitian adalah sebagai berikut:

1. Melakukan tinjauan langsung ke lapangan
Gorga Jurnal Seni Rupa

Volume 08 Nomor 01 Januari-Juni 2019

p-ISSN: 2301-5942 | e-ISSN: 2580-2380

2. Membuat deskripsi atau gambaran yang sejelasjelasnya tentang penerapan prinsip-prinsip desain yaitu prinsip kesatuan, keseimbangan, irama, penekanan, dan proporsi.

3. Menguraikan teori dan data mengenai kerajinan souvenir diorama berdasarkan prinsip-prinsip desain.

4. Mengkategorikan prinsip-prinsip desain yaitu prinsip kesatuan, keseimbangan, irama, penekanan dan proporsi kedalam indikator skala penilaian pada lembar penilaian.

5. Lembar penilaian diberikan kepada masing-masing tim penilai yang telah dipilih oelh peneliti untuk menilai objek yang akan diteliti. Tim penilai yang dipilih yaitu dua penilai merupakan Dosen Seni Rupa Universitas Negeri Medan dan satu penilai merupakan pendesain di bagian advertising sekaligus pemilik usaha tersebut.

6. Hasil penilaian yang telah dinilai oleh tim penilai nantinya akan dikembalikan pada peneliti untuk di analisis. Kemudian peneliti menggabungkan hasil penilaian dari 3 tim penilai dan diperoleh nilai rata-rata dari 10 karya berdasarkan 5 aspek yang telah dinilai yaitu prinsip kesatuan, keseimbangan, irama, penekanan dan proporsi.

7. Setelah itu melakukan rekapitulasi penilaian dengan mentabulasikan data selanjutna menarik kesimpulan hasil penelitian.

\section{HASIL DAN PEMBAHASAN}

1.Hasil

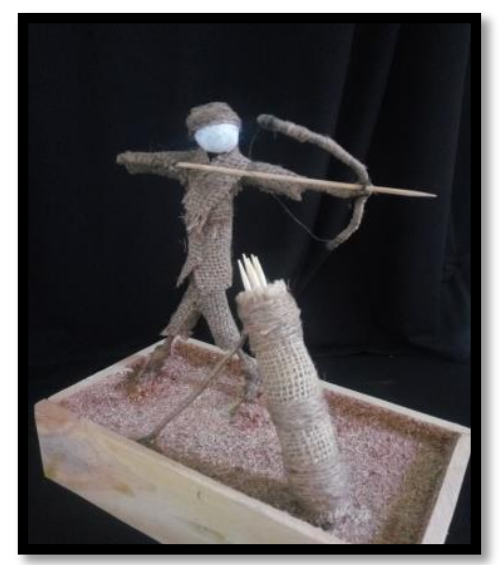

Gambar 1. Diorama Boneka Sedang Memanah (Sumber: Lisa Saragih, 2018)

Kesatuan pada karya ini secara keseluruhan baik, hanya saja kurangnya elemen pendukung sehingga pada tingkat kerapatanya masih terlihat kurang menarik. Keseimbangan pada karya ini secara keseluruhan baik hal ini disebabkan karena pengaruh arah pandang boneka yang membuat karya ini terlihat seimbang. Keseimbangan pada karya ini termasuk keseimbangan asimetris. Irama pada karya ini secara 


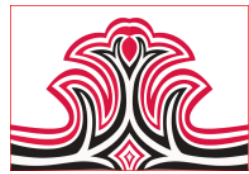

keseluruhan cukup baik, karena tidak memiliki banyak elemen yang disusun berulang-ulang. Penekanan pada karya ini secara keseluruhan baik, karena adanya kontras warna yang menonjol pada karya ini . Proporsi pada boneka ini baik karna memiliki bentuk tubuh yang unik, namun secara keseluruhan cukup baik karena antara alas dan objek nya terlihat kurang proporsional.

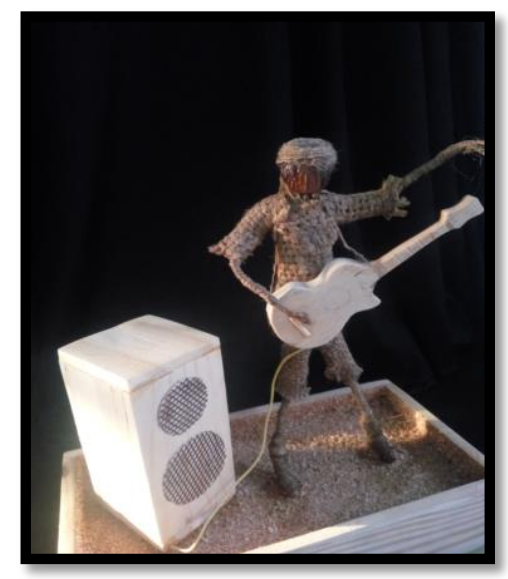

Gambar 2. Diorama Boneka Sedang Bermain Gitar (Sumber: Lisa Saragih, 2018)

Kesatuan pada karya ini secara keseluruhan baik karena adanya keselarasan antar objek dan warnanya juga terlihat harmonis. Keseimbangan pada karya ini secara keseluruhan baik pengaruh arah pandang boneka yang membuat karya ini terlihat seimbang. Keseimbangan pada karya ini termasuk keseimbangan asimetris. Irama pada karya ini secara keseluruhan cukup baik, karena tidak memiliki banyak elemen yang disusun berulang-ulang. Penekanan pada karya ini secara keseluruhan baik karena adanya bentuk yang menonjol pada karya ini. Proporsi pada karya ini secara keseluruhan sangat baik karena antara alas dan objeknya terlihat seimbang dan pada boneka memiliki tubuh yang unik.

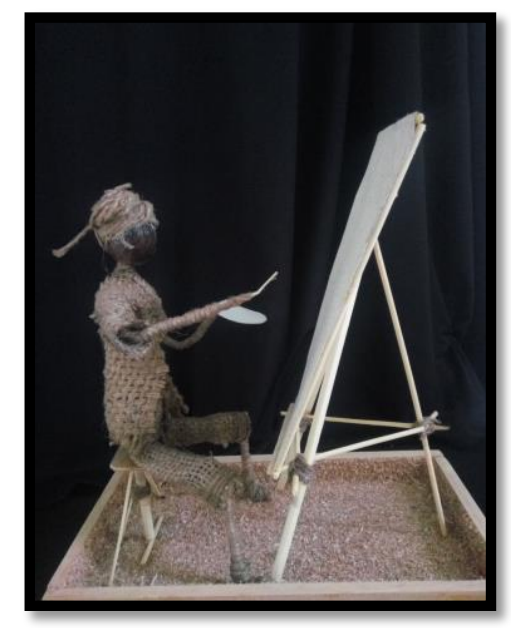

Gambar 3. Diorama Boneka Sedang Melukis (Sumber: Lisa Saragih, 2018)
Gorga Jurnal Seni Rupa

Volume 08 Nomor 01 Januari-Juni 2019

p-ISSN: 2301-5942 | e-ISSN: 2580-2380

Kesatuan pada karya ini secara keseluruhan baik karena warna pada tiap objeknya terlihat harmonis hanya saja pada tingkat kerapatannya yang kurang. Keseimbangan pada karya ini baik terlihat dari bagaimana penyusunan objeknya. Keseimbangan pada karya ini termasuk keseimbangan sederajat. Irama pada karya ini secara keseluruhan baik karena adanya keberkalan bentuk dan keberkalaan jaraknya. Penekanan pada karya ini secara keseluruhan baik karna adanya unsur yang menonjol dalam karya ini. Proporsi pada karya ini secara keseluruhan baik karena antara alas dan objeknya disusun seimbang dan pada boneka memiliki bentuk tubuh yang unik.

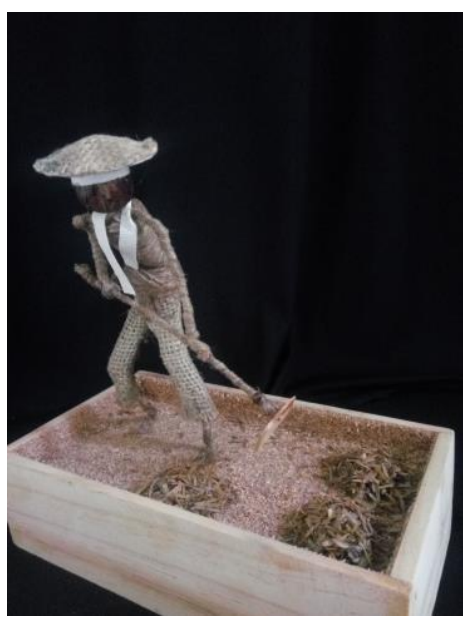

Gambar 4. Diorama Boneka Sedang Mencangkul (Sumber: Lisa Saragih, 2018)

Kesatuan pada karya ini secara keseluruhan cukup baik karena eleen pendukung pada karya sangat minim sehingga tidak dapat menampilkan kesan harmonis. Keseimbangan pada karya ini secara keseluruhan cukup baik, namun ksesimbangan ini bisa dikatakan keseimbangan asimetris karna keseimbangan ini hanya dapat dirasaka n dengan kepekaan estetis. Irama pada karya ini secara keseluruhan cukup baik karena elemen yang ditampilkan sangat sedikit sehingga tidak terdapat bentuk yang disusun teratur dan berulangulang. Penekanan pada karya ini secara keseluruhan baik karna terdapat kontras warna yang menonjol pada karya ini. Proporsi boneka pada karya ini baik karena memiliki bentuk tubuh unik, namun proporsi secara keseluruhan cukup baik karna kurangnya elemen sehingga banyak menyisakan ruang kosong pada alas karyanya. 

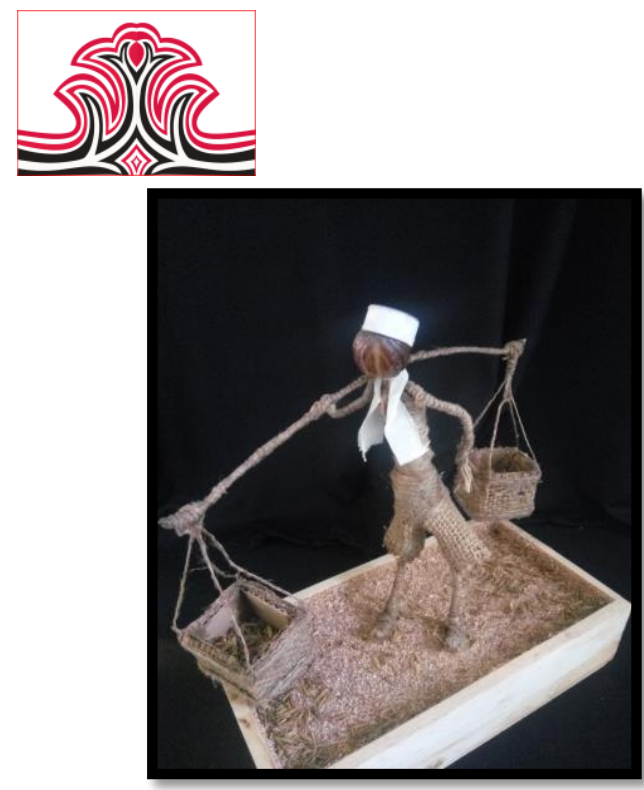

Gambar 5. Diorama Boneka Sedang Berjualan (Sumber: Lisa Saragih, 2018)

Kesatuan pada karya ini secara keseluruhan baik karna adanya unsur kerapatan antara boneka dengan elemen nya dan memiliki warna yang harmonis. Keseimbangan pada karya ini secara keseluruhan baik karena memiliki ukuran, bentuk yang sama antara ruas kiri dan kanan. Keseimbangan ini termasuk dalam keseimbangan simetris. Irama pada kara ini secara keseluruhan baik karna tiap objek nya dikomposisikan dengan baik sehingga memperlihatkan keberkalaan ukuran yang dapat menciptakan kesan irama. Penekanan pada karya ini secara keseluruhan baik kana terdapat kontras warna yang menonjol pada karya tersebut. Proporsi pada boneka ini baik karna memiliki bentuk tubuh yang unik namun proporsi secara keseluruhan cukup baik karna kurangnya elemen sehingga banyak menyisakan ruang kosong pada alas karya.

\section{KESIMPULAN DAN SARAN}

\section{Kesimpulan}

Berdasarkan hasil penelitian yang diuraikan, maka dapat disimpulkan sebagai berikut:

1. Karya kerajinan souvenir diorama berbahan limbah secara keseluruhan sudah menerapkan prinsip-prinsip desain dengan baik dengan nilai rata-rata 83 namun pada masing-masing karya masih terdapat beberapa prinsip yang belum diterapkan sepenuhnya. Seperti prinsip kesatuan pada karya 4,8, prinsip keseimbangan pada karya $4,7,9$, prinsip irama pada karya $1,2,4,6,10$, dan prinsip penekanan pada karya 6 .

2. Pada 10 karya kerajinan diorama berbahan limbah terdapat 7 karya dengan nilai rata-rata 84.7 termasuk dalam kategori baik yaitu karya 1,2,3,5,7,9,10 dan 3 karya dengan nilai rata-rata 79.1 termasuk dalam kategori cukup baik yaitu karya 4,6,8.
Gorga Jurnal Seni Rupa

Volume 08 Nomor 01 Januari-Juni 2019

p-ISSN: 2301-5942 | e-ISSN: 2580-2380

3. Prinsip kesatuan dari beberapa karya diorama pada pengrajin Dikraf terlihat baik dari bagaimana penyusunan boneka dengan elemen yang digunakannya. Prinsip keseimbangan dari beberapa karya diorama terlihat dari keseimbangan antara seluruh elemen dengan alas karya, boneka dengan elemen lainnya, serta keseimbangan antar elemen. Prinsip irama dari beberapa karya diorama terlihat cukup baik karna tidak terdapat elemen yang disusun berulang-ulang. Prinsip penekanan pada beberapa karya diorama terlihat dari kontras warna yang menonjol pada karya. Prinsip proporsi pada seluruh karya diorama terlihat dari baik dari keunikan proporsi yang terdapat pada boneka.

4. Potensi pengembangan yang perlu dilakukan pada karya kerajinan diorama berbahan limbah yang pertama adalah pemilihan bahan yang akan digunakan, penambahan elemen-elemen pendukung nya dan penyesuaian alas karya dengan objeknya.

5. Peneliti menyimpulkan bahwa karya diorama yang dihasilkan Dikraf dari keseluruhan sampel yang digunakan dalam penelitian ini terdapat aspek desain yang paling menonjol diantara prinsip lainnya yaitu pada prinsip proporsi. Dimana prinsip ini mendapat rating penilaian paling baik dari masing-masing penilai. Prinsip proporsi terlihat dari keunikan tubuh boneka yang memiliki ukuran tangan lebih panjang daripada ukuran kakinya dan ukuran tubuh boneka lebih panjang dari ukuran tubuh manusia sesungguhnya. Kemudian prinsip yang paling lemah diantara prinsip lainnya yaitu prinsip irama dimana pada prinsip ini mendapat rating penilaian terendah dari masing-masing penilai. Prinsip ini terlihat lemah dari segi elemen yang digunakannya sehingga sulit bagi pengamat untuk melihat kesan irama yang terdapat didalam karya diorama tersebut.

\section{Saran}

Saran yang dapat diberikan kesimpulan terkait dengan penelitian ini adalah:

1. Pengrajin sebaiknya selektif dalam memilih bahan, bentuk, serta warna yang digunakan sebagai elemen pendukung dalam pembuatan karya diorama agar terlihat lebih menarik.

2. Pengrajin sebaiknya menyesuaikan antara tema dengan elemen yang akan digunakan agar tidak menyisakan bagian-bagian kosong pada alas karyanya.

3. Pada bagian alas karya, pengrajin sebaiknya mengkreasikan bentuk-bentuk unik serta menggunakan bahan lain agar alas karya tersebut memiliki bentuk yang bervariasi sehingga 
mampu menggundang daya tarik pembeli. Besar alas karya juga harus disesuaikan dengan besar boneka dan besar elemen lainnya agar karya terlihat lebih menarik.

4. Pengrajin sebaiknya memberi kemasan yang baik agar karya tersebut tidak mudah rusak dan tidak mudah kotor.

5. Pengerajin sebaiknya mengkombinasikan antara karung goni dengan kain perca. Kain perca yang digunakan seperti kain batik, dan ulos. Hal ini bertujuan agar karya tersebut lebih menarik serta menambah ciri khas suatu daerah.

\section{DAFTAR RUJUKAN}

Arikunto, Suharsimi. (2010). Prosedur Penilitian (Suatu Pendekatan Praktek). Jakarta: Rineka Cipta.

Griffith, David. (2013). Ship Dioramas Bringing Your Models to Life. China: Seaforth.

Raharjo, Timbul. (2011). Seni Kriya dan Kerajinan. Yogyakarta: ISI Yogyakarta.

Stewart, Mary. (2011). Launching the Imagination a Comprehensive Guide to Basic Design. New York: McGraw-Hill.

Sugiyono. (2014). Metode Penelitian (Pendekatan Kuantitatif, kualitatif, dan $R \& D)$. Bandung: Alfabeta.

Yudhi, Munadi. (2013). Media Pembelajaran:Sebuah Pustaka Baru. Jakarta Selatan: GP Press.

Zulkifli. dan Triyanto, R. (2018). Nirmana Dwimatra Elemen, Prinsip, dan Aspek Aplikasi Teknis Seni Rupa dan Desain. Medan: FBS Unimed Press. 